\title{
TUJUAN PENDIDIKAN DAN HASIL BELAJAR: DOMAIN DAN TAKSONOMI
}

Oleh : Purwanto*)

\section{Abstrak}

Tujuan pendidikan merupakan perubahan perilaku yang direncanakan dalam aktivitas belajar mengajar. Hasil belajar merupakan hasil yang dicapai dari aktivitas belajar mengajar sesuai dengan tujuan pendidikan. Hasil belajar diukur untuk mengetahui pencapaian tujuan pendidikan, sehingga hasil belajar harus paralel dengan tujuan pendidikan. Hasil belajar merupakan perubahan perilaku yang dicapai setelah anak mengikuti proses belajar mengajar. Anak mempunyai potensi dalam perilaku psikologis yang dapat dididik dan diubah perilakunya. Potensi itu adalah domain kognitif, afektif dan psikomotorik. Belajar merupakan usaha membuat perubahan perilaku dalam domain kognitif, afektif dan psikomotorik. Domain dalam perilaku psikologis bukanlah kapasitas tunggal. Untuk tujuan pengukuran, domain hasil belajar disusun secara hirarkhis dalam tingkat-tingkat mulai tingkat terendah dan sederhana hingga tertinggi dan paling kompleks. Domain kognitif dapat diklasifikasikan menjadi tingkat hafalan, pemahaman, penerapan, analisis, sintesis dan evaluasi. Domain afektif terdiri dari tingkat penerimaan, respons, penilaian, organisasi dan karakterisasi. Domain psikomotorik dapat diklasifikasikan menjadi persepsi, kesiapan, respons terbimbing, mekanisme, respons kompleks, adaptasi dan keaslian

Kata kunci : tujuan pendidikan, hasil belajar, domain, taksonomi

*) Purwanto, M.Pd., adalah Dosen STAIN Surakarta. 


\section{A. PENDAHULUAN}

Untuk dapat melakukan evaluasi hasil belajar, diadakan pengukuran terhadap hasil belajar. Pengukuran adalah kegiatan membandingkan sesuatu dengan alat ukurnya (Arikunto, 1995 : 3). Dalam pendidikan, pengukuran hasil belajar dilakukan dengan mengadakan testing untuk membandingkan kemampuan siswa yang diukur dengan tes sebagai alat ukurnya.

Hasil belajar merupakan perubahan perilaku siswa akibat belajar. Perubahan itu diupayakan dalam proses belajar-mengajar untuk mencapai tujuan pendidikan. Perubahan perilaku individu akibat proses belajar tidaklah tunggal. Setiap proses belajar mempengaruhi perubahan perilaku pada domain tertentu pada diri siswa, tergantung perubahan yang diinginkan terjadi sesuai dengan tujuan pendidikan.

Dalam pengembangan alat ukur hasil belajar perlu dipahami domain yang akan diukur sebelum menyusun alat ukur. Pemahaman terhadap domain yang akan diukur menentukan apakah alat ukur yang dikembangkan tepat sehingga pengukuran dan hasilnya juga tepat.

Kepribadian manusia secara teoretik untuk kepentingan memahami perubahan perilaku manusia dibagi menjadi tiga domain atau ranah, yaitu kognitif, afektif, dan psikomotorik. Setiap proses belajar mempengaruhi perubahan perilaku. Tergantung pada tujuan pendidikannya, perubahan perilaku yang merupakan hasil belajar dapat berupa domain kognitif, afektif, atau psikomotorik.

Perubahan dalam setiap domain tidaklah tunggal. Setiap domain terdiri dari beberapa jenjang hasil belajar mulai dari yang paling rendah dan sederhana sampai dengan yang paling tinggi dan kompleks. Tingkatan disusun dalam sebuah taksonomi yang 
mencerminkan tingkat kompleksitas jenjang.

Tulisan ini membahas tentang tujuan pendidikan, hasil belajar, domain, dan taksonominya agar dapat menjadi panduan dalam memahami domain dan taksonomi tujuan pendidikan serta hasil belajar yang diukur dalam rangka menyusun alat ukur yang tepat untuk mengumpulkan data hasil belajar.

\section{B. TUJUAN PENDIDIKAN}

Tujuan pendidikan adalah perubahan perilaku yang diinginkan terjadi setelah siswa belajar. Tujuan pendidikan dapat dijabarkan mulai dari tujuan nasional, institusional, kurikuler sampai instruksional (Arikunto, 1995 : 130). Untuk dapat mencapai tujuan pendidikan nasional, maka tujuan pembangunan nasional dalam sektor pendidikan diturunkan ke dalam beberapa tujuan pendidikan, mulai dari tujuan nasional hingga tujuan di tingkat pengajaran.

Tujuan nasional pendidikan adalah cita-cita negara terhadap warga negara setelah mengikuti pendidikan. Tujuan nasional sangat dipengaruhi oleh arah yang diinginkan oleh pembangunan bangsa dalam sektor pendidikan. Misalnya tujuan nasional pendidikan di Indonesia yang pernah termuat dalam Garis-garis Besar Haluan Negara : "Tujuan pendidikan adalah meningkatkan ketakwaan kepada Tuhan Yang Maha Esa, mempertinggi budi pekerti, mencerdaskan kehidupan bangsa, meningkatkan keterampilan, ....".

Tujuan nasional pendidikan merupakan tujuan yang terlalu luas untuk dilihat perubahan perilakunya dan diukur. Untuk kepentingan mempermudah pengukurannya, tujuan nasional pendidikan dioperasionalisasikan ke dalam tujuan institusional yaitu tujuan pendidikan pada masing-masing jenjang dan jenis lembaga. Tiap lembaga memiliki tujuan yang berbeda-beda. SD, MI, SMP, MTs, SMU, SMK, MA, Perguruan Tinggi Umum, Perguruan Tinggi Agama dan Perguruan Tinggi Kedinasan, dan sebagainya mempunyai tujuan yang berbeda-beda yang disebut tujuan institusional. Tujuan 
institusional merupakan penjabaran dari tujuan nasional pendidikan. Ketercapaian tujuan-tujuan institusional mendukung tercapainya tujuan nasional pendidikan.

Tujuan institusional juga belum dapat dilihat perubahan perilakunya sehingga belum dapat diukur. Agar lebih operasional tujuan institusional dijabarkan ke dalam tujuan untuk setiap bidang studi/ mata pelajaran/mata kuliah yang disebut tujuan kurikuler.Tiap mata pelajaran/mata kuliah mempunyai tujuan yang berbeda-beda. Mata pelajaran olah raga, matematika, bahasa Indonesia, bahasa Inggris, agama Islam, sejarah, ekonomi, dan sebagainya mempunyai tujuan yang berbeda-beda.

Tujuan kurikuler juga belum dapat dilihat perubahan perilaku dan diukur sehingga dijabarkan lagi ke dalam tujuan pendidikan pada tingkat pengajaran yang disebut tujuan instruksional. Setiap mata pelajaran/ mata kuliah disampaikan ke dalam beberapa pertemuan. Setiap pertemuan mempunyai tujuan atau mengadakan perubahan perilaku yang berbeda dengan pertemuan lainnya. Tujuan instruksional dijabarkan dari tujuan kurikuler yang tertuang dalam kurikulum. Pencapaian tujuan instruksional akan mendukung tercapainya tujuan kurikuler.

Tujuan instruksional dapat berupa tujuan yang bersifat umum dan khusus. Tujuan instruksional umum (TIU) adalah tujuan pengajaran yang perubahan perilaku siswa yang belajar masih merupakan perubahan internal yang belum dapat dilihat dan diukur. Kata kerja dalam tujuan umum pengajaran masih mencerminkan perubahan perilaku yang umumnya terjadi pada manusia, sehingga masih menimbulkan beberapa penafsiran yang berbeda-beda.

Tujuan instruksional khusus (TIK) adalah tujuan pengajaran di mana perubahan perilaku telah dapat dilihat dan diukur. Kata kerja yang menggambarkan perubahan perilaku telah spesifik sehingga memungkinkan dilakukan pengukuran tanpa menimbulkan lagi berbagai perbedaan penafsiran. Contoh TIU: "Setelah mengikuti 
pelajaran, siswa diharapkan dapat memahami penjumlahan dengan benar". Kata kerja "memahami penjumlahan" merupakan kata kerja yang bersifat umum karena pemahaman penjumlahan dapat ditafsirkan berbeda-beda. Pada siswa SD/MI kelas I, pemahaman penjumlahan adalah "kemampuan menghitung penjumlahan 0 $10 "$.

Pada siswa SMU / MA, pemahaman penjumlahan mungkin ditafsirkan sebagai "kemampuan memahami hukum-hukum penjumlahan". Perbedaan dalam mendefinisikan "memahami penjumlahan" dapat menimbulkan kesalahan dalam melakukan pengukuran dengan memberikan butir-butir tes yang tidak sesuai. Misalnya siswa SMU/MA diberikan tes menghitung penjumlahan 0 - 10. Agar tidak menimbulkan perbedaan penafsiran, maka TIU dijabarkan ke dalam TIK. TIK dirumuskan berdasarkan TIU sesuai dengan kondisi yang dihadapi guru. Sebuah TIU dapat dijabarkan ke dalam beberapa TIK untuk mencapainya. Misalnya dari TIU : "Setelah mengikuti pelajaran diharapkan siswa dapat memahami penjumlahan dengan benar", karena siswa yang diukur kemampuannya adalah siswa SD/MI kelas I maka dari TIU tersebut dapat dirumuskan TIK yang salah satunya: "Setelah mengikuti pelajaran diharapkan siswa dapat menghitung penjumlahan 0 10 paling tidak 8 soal".

Tujuan pengajaran dirumuskan dengan rumus $\mathrm{ABCD}$. A (audience) adalah siswa yang belajar, $\mathrm{B}$ (behaviour) adalah perubahan perilaku yang diinginkan terjadi, C (condition) adalah kondisi yang menimbulkan perubahan perilaku yang diinginkan, dan $\mathrm{D}$ (degree) adalah derajat ketercapaian perubahan perilaku. Misalnya: "Setelah membaca di perpustakaan, (C) siswa (A) diharapkan dapat menyebutkan enam macam shalat sunah (B) secara benar (D)".

\section{HASIL BELAJAR}

Belajar merupakan proses dalam diri individu yang berinteraksi 
dengan lingkungan untuk mendapatkan perubahan dalam perilakunya. Belajar adalah aktivitas mental/psikis yang berlangsung dalam interaksi aktif dengan lingkungan yang menghasilkan perubahan-perubahan dalam pengetahuan, keterampilan, dan sikap (Winkel, 1999 : 53). Perubahan itu diperoleh melalui usaha (bukan karena kematangan), menetap dalam waktu yang relatif lama dan merupakan hasil pengalaman.

Minat terhadap kajian terhadap proses belajar dilandasi oleh keinginan untuk memberikan pelayanan pengajaran dengan hasil yang maksimal. Pengajaran merupakan proses membuat belajar terjadi di dalam diri anak. Pengajaran bukanlah menginformasikan materi agar dikuasai oleh mahasiswa, tetapi memberikan kondisi agar mahasiswa mengusahakan terjadi belajar dalam dirinya. Mahasiswa tidaklah dalam kedudukan yang pasif, tapi aktif mengusahakan terjadinya proses belajarnya sendiri. Oleh karena itu, pengajaran dilakukan untuk membuat mahasiswa melakukan belajar, maka pengajaran akan dilakukan secara baik dengan memahami bagaimana proses belajar terjadi pada mahasiswa. Pengajaran harus didasarkan atas pemahaman tentang bagaimana anak belajar.

Kajian intensif tentang bagaimana manusia belajar telah banyak dilakukan oleh para ahli, mulai dari tinjauan yang bersifat spekulatif oleh para filsuf hingga tinjauan dengan pendekatan modern oleh para ahli psikologi modern. Tinjauan menggunakan pendekatan spekulatif muncul sebelum abad XX, sedang tinjauan kedua muncul sesudahnya. Tinjauan yang bersifat spekulatif dirintis oleh Plato dan Aristoteles dengan ilmu jiwa daya, Jean J. Rousseau, Heinrich Pestalozzi dan Friedrich dengan teori perkembangan alamiahnya, dan John Friedrich Herbart dengan teori apersepsi. Kajian yang bersifat behavioral experiment berdasarkan filsafat empirisme dipelopori ahli psikologi experiment seperti Edward L. Thorndike, Ivan Petrovich Pavlov, BF Skinner dan ER Guthrie. Penjelasan yang 
bersifat kognitif berdasarkan filsafat rasionalisme diberikan oleh teoritisi seperti Albert Bandura, Robert M. Gagne, Jerome Brunner, David Ausuble dan Piaget.

Pendekatan spekulatif sebelum abad XX tidak didasarkan atas metode ilmiah yang dapat dipertanggungjawabkan. Hasilnya tidak ilmiah, bersifat spekulatif dan tidak dapat diuji kebenarannya. Kekurangan ini menjadi alasan munculnya pendekatan modern yang ilmiah dan dapat dipertanggungjawabkan. Pendekatan modern secara garis besar terdiri dari dua aliran yang menghasilkan teori masing-masing, yaitu teori belajar perilaku dan teori belajar kognitif.

Teori ini diilhami oleh aliran empirisme dalam pendidikan yang dipelopori oleh John Locke. Menurut aliran ini, satu-satunya determinan perkembangan manusia adalah lingkungan. Semua pengalaman merupakan akibat dari interaksi individu dengan lingkungan. Pengalaman datangnya dari indera (sensory). Pengalaman inderawi adalah sumber utama pengetahuan dan perubahan perilaku.

Dalam pandangan behavioristik, belajar merupakan sebuah perilaku membuat hubungan antara stimulus $(S)$ dan respons $(R)$, kemudian memperkuatnya. Pengertian dan pemahaman tidaklah penting karena $S$ dan $R$ dapat diperkuat dengan menghubungkannya secara berulang-ulang untuk memungkinkan terjadinya proses belajar dan menghasilkan perubahan yang diinginkan. Belajar adalah perubahan perilaku yang dapat diamati melalui kaitan antara stimulus dan respons menurut prinsip yang mekanistik (Dahar, 1998 : 24). Dasar belajar adalah asosiasi antara kesan (impression) dengan dorongan untuk berbuat (impuls to action). Asosiasi itu menjadi kuat atau lemah dengan terbentuknya atau hilangnya kebiasaan-kebiasaan (Bower dan Hilgard, 1981 : 21). Pengulangan dapat menimbulkan tingkah laku dengan mengubah respons bersyarat menjadi respons tanpa syarat (Bower dan Hilgard, 1981 : 49). 
Para behaviorist meyakini bahwa hasil belajar akan lebih baik dikuasai kalau dihafal secara berulang-ulang. Belajar terjadi karena adanya ikatan antara stimulus dan respons ( $S-R$ bonds). Ikatan itu menjadi makin kuat dalam latihan/pengulangan dengan cara menghafal. Belajar tidak membutuhkan pengertian dan pemahaman karena terbentuknya hanya dengan mengikatkan $S$ dan $\mathrm{R}$ secara berulang-ulang. Teori ini didukung oleh hasil eksperimen yang dilakukan oleh para ahli psikologi eksperimental seperti Thorndike, Pavlov, Skinner, dan Guthrie.

Teori belajar kognitif diilhami oleh aliran rasionalisme dalam filsafat. Pengetahuan datangnya dari penalaran. Penalaran merupakan sumber valid dari pengetahuan. Panca indera itu tidak terstruktur, acak dan hanya memberikan bahan untuk belajar. Di atas itu semua, pikiran yang aktif bekerja.

Keharusan akan perlunya pengertian dan pemahaman dalam belajar menjadi kondisi yang mutlak harus terpenuhi dalam pandangan teori kognitif. Menurut teori ini, belajar berlangsung dalam pikiran sehingga sebuah perilaku hanya disebut belajar apabila siswa yang belajar telah mencapai pemahaman (understanding).

Dalam teori belajar kognitif, seseorang hanya dapat dikatakan belajar apabila telah memahami keseluruhan persoalan secara mendalam (insightful). Memahami itu berkaitan dengan proses mental: bagaimana impresi indera dicatat dan disimpan dalam otak dan bagaimana impresi-impresi itu digunakan untuk memecahkan masalah (Dahar, 1998 : 25). Belajar yang bersifat mekanistik dan tanpa pemahaman dipertanyakan manfaatnya. Pemecahan masalah tidak dapat dilakukan dengan menggunakan informasi yang tidak bermakna.

Menurut Gagne, hasil belajar adalah terbentuknya konsep, yaitu kategori yang kita berikan pada stimulus yang ada di lingkungan, 
yang menyediakan skema yang terorganisasi untuk mengasimilasi stimulus-stimulus baru dan menentukan hubungan di dalam dan di antara kategori-kategori (Dahar, 1998 : 95). Skema itu akan beradaptasi dan berubah selama perkembangan kognitif seseorang (Suparno, 2001 : 21). Oleh karenanya menurut Bruner, belajar menjadi bermakna apabila dikembangkan melalui eksplorasi penemuan. Mengajar adalah "....to provide learners with more opportunities to expand their knowledge by developing and testing hypotheses rather than merely reading or listening to the teacher" (Good dan Brophy, 1990 : 192).

Proses belajar dapat melibatkan aspek kognitif, afektif dan psikomotorik. Pada belajar kognitif, prosesnya mengakibatkan perubahan dalam aspek kemampuan berpikir (cognitive), pada belajar afektif mengakibatkan perubahan dalam aspek kemampuan merasakan (affective), sedang belajar psikomotorik memberikan hasil belajar berupa keterampilan (psychomotoric).

Proses belajar merupakan proses yang unik dan kompleks. Keunikan itu disebabkan karena hasil belajar hanya terjadi pada individu yang belajar, tidak pada orang lain, dan setiap individu menampilkan perilaku belajar yang berbeda. Perbedaan penampilan itu disebabkan karena setiap individu mempunyai karakteristik individualnya yang khas, seperti minat, intelegensi, perhatian, bakat, dan sebagainya. Setiap manusia mempunyai cara yang khas untuk mengusahakan proses belajar terjadi dalam dirinya. Individu yang berbeda dapat melakukan proses belajar dengan kemampuan yang berbeda dalam aspek kognitif, afektif, dan psikomotorik. Begitu pula, individu yang sama mempunyai kemampuan yang berbeda dalam belajar aspek kognitif, afektif, dan psikomotorik.

Berdasarkan teori belajar di atas dapat disimpulkan bahwa belajar adalah proses untuk membuat perubahan dalam diri mahasiswa dengan cara berinteraksi dengan lingkungan untuk mendapatkan perubahan dalam aspek kognitif, afektif, dan psikomotorik. Pada 
teori belajar perilaku, proses belajar cukup dilakukan dengan mengikatkan antara stimulus dan respons secara berulang, sedang pada teori kognitif, proses belajar membutuhkan pengertian dan pemahaman.

Pada umumnya, tujuan pendidikan dapat dimasukkan ke dalam salah satu dari tiga ranah, yaitu kognitif, afektif, dan psikomotorik (Subino, 1987 : 17). Belajar dimaksudkan untuk menimbulkan perubahan perilaku yaitu perubahan dalam aspek kognitif, afektif, dan psikomotorik. Perubahan-perubahan dalam aspek itu menjadi hasil dari proses belajar. Perubahan perilaku hasil belajar itu merupakan perubahan perilaku yang relevan dengan tujuan pengajaran. Oleh karenanya, hasil belajar dapat berupa perubahan dalam kemampuan kognitif, afektif, dan psikomotorik, tergantung dari tujuan pengajarannya.

Hasil belajar seringkali digunakan sebagai ukuran untuk mengetahui seberapa jauh seseorang menguasai bahan yang sudah diajarkan. Untuk mengaktualisasikan hasil belajar tersebut diperlukan serangkaian pengukuran menggunakan alat evaluasi yang baik dan memenuhi syarat. Pengukuran demikian dimungkinkan karena pengukuran merupakan kegiatan ilmiah yang dapat diterapkan pada berbagai bidang termasuk pendidikan.

Hasil belajar dapat dijelaskan dengan memahami dua kata yang membentuknya, yaitu "hasil" dan "belajar". Pengertian hasil (product) menunjuk kepada suatu perolehan akibat dilakukannya suatu aktivitas atau proses yang mengakibatkan berubahnya input secara fungsional. Hasil produksi adalah perolehan yang didapatkan karena adanya kegiatan mengubah bahan (raw materials) menjadi barang jadi (finished goods). Hal yang sama berlaku untuk memberikan batasan bagi istilah hasil panen, hasil penjualan, hasil pembangunan, termasuk hasil belajar. Dalam siklus input-proses-hasil, hasil dapat dengan jelas dibedakan dengan input akibat perubahan oleh proses. Begitu pula dalam kegiatan belajarmengajar, setelah mengalami belajar, siswa berubah perilakunya 
dibanding sebelumnya.

Belajar dilakukan untuk mengusahakan adanya perubahan perilaku pada individu yang belajar. Perubahan perilaku itu merupakan perolehan yang menjadi hasil belajar. Hasil belajar adalah perubahan yang mengakibatkan manusia berubah dalam sikap dan tingkah lakunya (Winkel, 1996 : 51). Aspek perubahan itu mengacu kepada taksonomi tujuan pengajaran yang dikembangkan oleh Bloom, Simpson, dan Harrow mencakup aspek kognitif, afektif, dan psikomotorik (Winkel, 1996 : 244).

Proses pengajaran merupakan sebuah aktivitas sadar untuk membuat siswa belajar. Proses sadar mengandung implikasi bahwa pengajaran merupakan sebuah proses yang direncanakan untuk mencapai tujuan pengajaran (goal directed). Dalam konteks demikian maka hasil belajar merupakan perolehan dari proses belajar siswa sesuai dengan tujuan pengajaran (ends are being attained). Tujuan pengajaran menjadi hasil belajar potensial yang akan dicapai oleh anak melalui kegiatan belajarnya. Oleh karenanya, tes hasil belajar sebagai alat untuk mengukur hasil belajar harus mengukur apa yang tidak di pelajari mahasiswa dalam proses belajar-mengajar sesuai dengan tujuan instruksional yang tercantum dalam kurikulum yang berlaku (Zainul dan Nasoetion, 1996 : 28) karena tujuan pengajaran adalah kemampuan yang diharapkan dimiliki oleh siswa setelah menyelesaikan pengalaman belajarnya (Sudjana, $1996: 2$ ).

Hasil belajar yang diukur merefleksikan tujuan pengajaran (Gronlund, 1985 : 20). Tujuan pengajaran adalah tujuan yang menggambarkan pengetahuan, keterampilan atau sikap yang harus dimiliki oleh siswa sebagai akibat dari hasil pengajaran yang dinyatakan dalam bentuk tingkah laku (behavior) yang dapat diamati dan diukur. Oleh karenanya, menurut Arikunto dalam merumuskan tujuan instruksional, harus diusahakan agar nampak bahwa setelah tercapainya tujuan itu terjadi adanya perubahan pada diri anak yang meliputi kemampuan intelektual, sikap/minat maupun keterampilan 
(Arikunto, 1995 : 131).

Perubahan perilaku akibat kegiatan belajar mengakibatkan siswa memiliki penguasaan terhadap materi pengajaran yang disampaikan dalam kegiatan belajar-mengajar untuk mencapai tujuan pengajaran. Pemberian tekanan penguasaan materi akibat perubahan dalam diri siswa setelah belajar diberikan oleh Soedijarto yang mendefinisikan hasil belajar sebagai tingkat penguasaan yang dicapai oleh mahasiswa dalam mengikuti proses belajar-mengajar sesuai dengan tujuan pendidikan yang ditetapkan (Soedijarto, 1993 : 49). Dengan memperhatikan berbagai teori di atas dapat disimpulkan bahwa hasil belajar adalah perubahan perilaku mahasiswa akibat belajar. Perubahan perilaku disebabkan karena dia mencapai penguasaan atas sejumlah bahan yang diberikan dalam proses belajar-mengajar. Pencapaian itu didasarkan atas tujuan pengajaran yang telah ditetapkan. Hasil itu dapat berupa perubahan dalam aspek kognitif, afektif maupun psikomotorik.

\section{TUJUAN PENDIDIKAN DAN HASIL BELAJAR}

Tujuan pendidikan direncanakan untuk dapat dicapai dalam proses belajar-mengajar. Hasil belajar merupakan pencapaian tujuan pendidikan pada siswa yang mengikuti proses belajar-mengajar. Tujuan pendidikan bersifat ideal, sedang hasil belajar bersifat aktual. Hasil belajar merupakan realisasi tercapainya tujuan pendidikan, sehingga hasil belajar yang diukur sangat tergantung kepada tujuan pendidikannya.

Hasil belajar perlu dievaluasi. Evaluasi dimaksudkan sebagai cermin untuk melihat kembali apakah tujuan yang ditetapkan telah tercapai dan apakah proses belajar-mengajar telah berlangsung efektif untuk memperoleh hasil belajar.

Belajar dalam arti luas adalah semua interaksi pribadi dengan lingkungan yang menimbulkan perubahan perilaku. Pengajaran adalah usaha yang memberi kesempatan agar proses belajar terjadi 
dalam diri siswa. Oleh karena belajar dapat terjadi ketika pribadi berinteraksi dengan lingkungan, maka pembelajaran terhadap siswa tidak hanya dilakukan di sekolah, sebab dunia adalah lingkungan belajar yang memungkinkan perubahan perilaku.

Meskipun pembelajaran dapat terjadi di lingkungan manapun namun satu-satunya pembelajaran yang dilakukan secara sistematis dilakukan di sekolah. Satu-satunya perbedaan antara pembelajaran yang dilakukan di sekolah dengan lingkungan lainnya adalah adanya tujuan pendidikan yang direncanakan untuk membuat perubahan perilaku. Tujuan pendidikan di sekolah mengarahkan semua komponen seperti metode mengajar, media, materi, alat evaluasi, dan sebagainya dipilih sesuai dengan tujuan pendidikan. Hasil belajar termasuk komponen pendidikan yang harus disesuaikan dengan tujuan pendidikan, karena hasil belajar diukur untuk mengetahui ketercapaian tujuan pendidikan melalui proses belajarmengajar.

\section{E. DOMAIN HASIL BELAJAR}

Belajar menimbulkan perubahan perilaku dan pembelajaran adalah usaha mengadakan perubahan perilaku dengan mengusahakan terjadinya proses belajar dalam diri siswa. Perubahan dalam kepribadian ditunjukkan oleh adanya perubahan perilaku akibat belajar.

Dalam usaha memudahkan memahami dan mengukur perubahan perilaku maka perilaku kejiwaan manusia dibagi menjadi tiga domain atau ranah, yaitu: kognitif, afektif, dan psikomotorik. Kalau belajar menimbulkan perubahan perilaku, maka hasil belajar merupakan hasil perubahan perilakunya. Oleh karena perubahan perilaku menunjukkan perubahan perilaku kejiwaan dan perilaku kejiwaan meliputi domain kognitif, afektif, dan psikomotorik, maka hasil belajar yang mencerminkan perubahan perilaku meliputi hasil belajar kognitif, afektif, dan psikomotorik. Selanjutnya untuk kepentingan pengukuran perubahan perilaku akibat belajar akan mencakup 


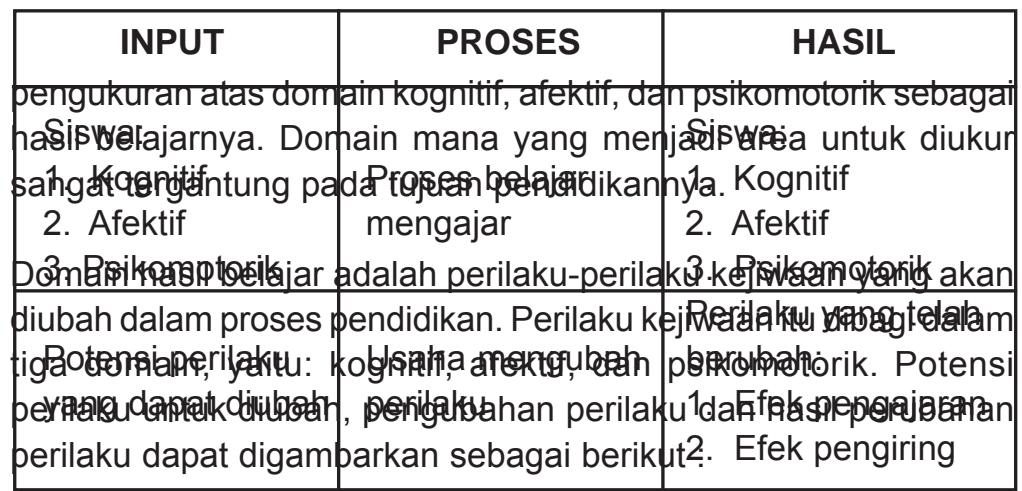

Setiap siswa mempunyai potensi untuk dididik. Potensi itu merupakan perilaku yang dapat diwujudkan menjadi kemampuan nyata. Potensi jiwa yang dapat diubah melalui pendidikan meliputi domain kognitif, afektif, dan psikomotorik. Pendidikan atau pembelajaran adalah usaha mengubah potensi perilaku kejiwaan agar mewujud menjadi kemampuan. Hasil belajar adalah perwujudan kemampuan akibat perubahan perilaku yang dilakukan oleh usaha pendidikan. Kemampuan menyangkut domain kognitif, afektif, dan psikomotorik.

Hasil belajar atau perubahan perilaku yang menimbulkan kemampuan dapat berupa hasil utama pengajaran (instructional effect) maupun hasil sampingan pengiring (nurturant effect). Hasil utama pengajaran adalah kemampuan hasil belajar yang memang direncanakan untuk diwujudkan dalam kurikulum dan tujuan pembelajaran. Sedang hasil pengiring adalah hasil belajar yang 
dicapai namun tidak direncanakan untuk dicapai. Misalnya setelah mengikuti pelajaran siswa menyukai pelajaran matematika yang semula tidak disukai karena siswa senang dengan cara mengajar guru.

\section{F. TAKSONOMI HASIL BELAJAR KOGNITIF}

Hasil belajar kognitif adalah perubahan perilaku yang terjadi dalam kawasan kognisi. Proses belajar yang melibatkan kognisi meliputi kegiatan sejak dari penerimaan stimulus eksternal oleh sensori, penyimpanan dan pengolahan dalam otak menjadi informasi hingga pemanggilan kembali informasi ketika diperlukan untuk menyelesaikan masalah. Oleh karena belajar melibatkan otak, maka perubahan perilaku akibatnya juga terjadi dalam otak berupa kemampuan tertentu oleh otak untuk menyelesaikan masalah.

Hasil belajar kognitif tidak merupakan kemampuan tunggal. Kemampuan yang menimbulkan perubahan perilaku dalam domain kognitif meliputi beberapa tingkat atau jenjang. Banyak klasifikasi dibuat para ahli psikologi dan pendidikan, namun klasifikasi yang paling banyak digunakan adalah yang dibuat oleh Benjamin S. Bloom (Good dan Brophy, 1990 : 722; Subino, 1987 : 57; Azwar, 1987 : 59 - 61; Arikunto, 1995 : 115 -117; Gronlund dan Linn, 1990 : 506; Suciati, 2001 : 17). Bloom membagi dan menyusun secara hirarkis tingkat hasil belajar kognitif mulai dari yang paling rendah dan sederhana yaitu hafalan sampai yang paling tinggi dan kompleks yaitu evaluasi. Makin tinggi tingkatannya maka makin kompleks dan penguasaan suatu tingkat mempersyaratkan penguasaan tingkat sebelumnya. Enam tingkat itu adalah hafalan (C1), pemahaman (C2), penerapan (C3), analisis (C4), sintesis (C5) dan evaluasi (C6).

Kemampuan menghafal (knowledge) merupakan kemampuan kognitif yang paling rendah. Kemampuan ini merupakan kemampuan memanggil kembali fakta yang disimpan dalam otak digunakan untuk merespons suatu masalah. Dalam kemampuan tingkat ini, fakta dipanggil kembali persis seperti ketika disimpan. 
Misalnya hari proklamasi kemerdekaan Republik Indonesia adalah 17 Agustus.

Kemampuan pemahaman (comprehension) adalah kemampuan untuk melihat hubungan fakta dengan fakta. Menghafal fakta tidak lagi cukup karena pemahaman menuntut pengetahuan akan fakta dan hubungannya. Misalnya memahami proses terjadinya hujan.

Kemampuan penerapan (application) adalah kemampuan kognitif untuk memahami aturan, hukum, rumus dan sebagainya dan menggunakan untuk memecahkan masalah. Misalnya sebuah bak air dengan panjang 2 meter, lebar 1,5 meter dan tinggi 1 meter, berapa volume air yang dapat dimuat?

Kemampuan menganalisis (analysis) adalah kemampuan memahami sesuatu dengan menguraikannya ke dalam unsurunsur. Kemampuan sintesis (synthesis) adalah kemampuan memahami dengan mengorganisasikan bagian-bagian ke dalam kesatuan. Kemampuan evaluasi (evaluation) adalah kemampuan membuat penilaian dan mengambil keputusan dari hasil penilaiannya.

\section{G. TAKSONOMI HASIL BELAJAR AFEKTIF}

Taksonomi hasil belajar afektif dikemukakan oleh Krathwohl (Winkel, 1996 : 247; Sudjana, 1990 : 29 - 30; Subino, $1987: 23$ 26; Gronlund dan Linn, 1990 : 508; Suciati, 2001 : 19). Krathwohl membagi hasil belajar afektif menjadi lima tingkat yaitu penerimaan, partisipasi, penilaian, organisasi, dan internalisasi. Hasil belajar disusun secara hirarkis mulai dari tingkat yang paling rendah dan sederhana hingga yang paling tinggi dan kompleks.

Penerimaan (receiving) atau menaruh perhatian (attending) adalah kesediaan menerima rangsangan dengan memberikan perhatian kepada rangsangan yang datang kepadanya. Partisipasi atau merespons (responding) adalah kesediaan memberikan respons 
dengan berpartisipasi. Pada tingkat ini, siswa tidak hanya memberikan perhatian kepada rangsangan tapi juga berpartisipasi dalam kegiatan untuk menerima rangsangan. Penilaian atau penentuan sikap (valuing) adalah kesediaan untuk menentukan pilihan sebuah nilai dari rangsangan tersebut. Organisasi adalah kesediaan mengorganisasikan nilai-nilai yang dipilihnya untuk menjadi pedoman yang mantap dalam perilaku. Internalisasi nilai atau karakterisasi (characterization) adalah menjadikan nilai-nilai yang diorganisasikan untuk tidak hanya menjadi pedoman perilaku tetapi juga menjadi bagian dari pribadi dalam perilaku sehari-hari.

\section{H. TAKSONOMI HASIL BELAJAR PSIKOMOTORIK}

Beberapa ahli mengklasifikasikan dan menyusun hirarki hasil belajar psikomotorik. Hasil belajar disusun dalam urutan mulai dari yang paling rendah dan sederhana sampai dengan yang paling tinggi dan kompleks. Hasil belajar tingkat yang lebih tinggi hanya dapat dicapai apabila siswa telah menguasai hasil belajar yang lebih rendah.Harrow misalnya (Subino, 1987 : 26 - 28; Sudjana, 1990 : 30 - 31) mengemukakan bahwa hasil belajar psikomotorik dapat diklasifikasikan menjadi enam, yaitu: gerakan refleks, gerakan fundamental dasar, kemampuan perseptual, kemampuan fisis, gerakan keterampilan, dan komunikasi tanpa kata. Namun taksonomi yang paling banyak digunakan adalah taksonomi hasil belajar psikomotorik dari Simpson (Winkel, 1996 : 249 - 250; Gronlund dan Linn, 1990 : 510) yang mengklasifikasikan hasil belajar psikomotorik menjadi enam, yaitu: persepsi, kesiapan, gerakan terbimbing, gerakan terbiasa, gerakan kompleks, dan kreativitas.

Persepsi (perception) adalah kemampuan hasil belajar psikomotorik yang paling rendah. Persepsi adalah kemampuan membedakan suatu gejala dengan gejala lain. Kesiapan (set) adalah kemampuan menempatkan diri untuk memulai suatu gerakan. Misalnya kesiapan menempatkan diri sebelum lari, menari, mengetik, memperagakan sholat, mendemonstrasikan penggunaan termometer dan 
sebagainya. Gerakan terbimbing (guided response) adalah kemampuan melakukan gerakan meniru model yang dicontohkan. Gerakan terbiasa (mechanism) adalah kemampuan melakukan gerakan tanpa ada model contoh. Kemampuan dicapai karena latihan berulang-ulang sehingga menjadi kebiasaan. Gerakan kompleks (adaptation) adalah kemampuan melakukan serangkaian gerakan dengan cara, urutan dan irama yang tepat. Kreativitas (origination) adalah kemampuan menciptakan gerakan-gerakan baru yang tidak ada sebelumnya atau mengkombinasikan gerakangerakan yang ada menjadi kombinasi gerakan baru yang orisinal.

\section{KESIMPULAN}

Tujuan pendidikan merupakan perubahan perilaku yang direncanakan dapat dicapai melalui proses belajar-mengajar. Hasil belajar adalah hasil yang dicapai dari proses belajar-mengajar sesuai dengan tujuan pendidikan. Hasil belajar diukur untuk mengetahui pencapaian tujuan pendidikan sehingga hasil belajar harus sesuai dengan tujuan pendidikan.

Hasil belajar adalah perubahan perilaku yang terjadi setelah mengikuti proses belajar-mengajar sesuai dengan tujuan pendidikan. Manusia mempunyai potensi perilaku kejiwaan yang dapat dididik dan diubah perilakunya yang meliputi domain kognitif, afektif, dan psikomotorik. Belajar mengusahakan perubahan perilaku dalam domain-domain tersebut sehingga hasil belajar merupakan perubahan perilaku dalam domain kognitif, afektif, dan psikomotorik.

Domain-domain dalam perilaku kejiwaan bukanlah kemampuan tunggal. Untuk kepentingan pengukuran hasil belajar, domaindomain disusun secara hirarkis dalam tingkat-tingkat, mulai dari yang paling rendah dan sederhana hingga yang paling tinggi dan kompleks. Domain kognitif diklasifikasikan menjadi kemampuan hafalan, pemahaman, penerapan, analisis, sintesa, dan evaluasi. 
Domain afektif hasil belajar meliputi tingkat: penerimaan, partisipasi, penilaian, organisasi, dan karakterisasi. Sedang domain psikomotorik terdiri dari tingkat: persepsi, kesiapan, gerakan terbimbing, gerakan terbiasa, gerakan kompleks, dan kreativitas.

\section{DAFTAR PUSTAKA}

Arikunto, Suharsimi (1995), Dasar-dasar Evaluasi Pendidikan Jakarta : Bumi Aksara

Azwar, Saifuddin (1987). Tes Prestasi. Yogyakarta : Liberty

Bower, Gordon H. dan Hilgard, Ernest R. (1981), Theories of Learning Englewood Cliffs, NJ : Prentice Hall Inc

Dahar, Ratna Wilis (1988), Teori-teori Belajar Jakarta : P2LPTK

Good, Thomas L. dan Brophy, Jere E (1990), Educational Psychology New York : Longman

Gronlund, Norman E (1985), Constructing Achievement Test Englewood Cliffs, NJ : Prentice Hall, Inc.

Gronlund, Norman E dan Linn, Robert L. (1985), Measurement and Evaluation in Teaching, New York : Macmillan Poblishing Company Soedijarto (1993), Menuju Pendidikan Nasional yang Relevan dan Bermutu (Jakarta : Balai Pustaka

Subino (1987), Konstruksi dan Analisis Tes Jakarta : Ditjen Dikti Suciati (2001). Taksonomi Tujuan Instruksional. Jakarta : Pusat Antar Universitas untuk Peningkatan dan Pengembangan Aktivitas Instruksional Ditjendikti Depdiknas

Sudjana, Nana (1990). Penilaian Hasil Proses Belajar Mengajar. Bandung : PT Remaja Rosdakarya

Sudjana, Nana (1996), Pembinaan dan Pengembangan Kurikulum di Sekolah Bandung : Sinar Baru

Suparno, Paul (2001), Teori perkembangan kognitif John Piaget Yogyakarta : Kanisius

Winkel, WS (1999), Psikologi Pengajaran Jakarta : PT Grasindo Zainul, Asmawi dan Nasoetion, Noehi (1996), Penilaian Hasil Belajar Jakarta : Ditjen Dikti Depdikbud. 